\title{
How to Improve Governance in Sub-Saharan Africa?
}

\author{
Siméon Maxime Bikoue \\ Advanced School of Economics and Commerce, University of Douala, P.O. Box 1931, Douala, Cameroon
}

\begin{abstract}
The aim of this paper is to try to explain governance failures in Sub-Saharan Africa and to identify reforms which can lead to good governance. The failures are mainly due to institutions that do not work properly, corruption, and lack of real democracy. Governance reforms can be both institutional and political. The political reforms should promote and reinforce democratic practices. Institutions should guarantee the rule of law and limit the elite's economic and political power.
\end{abstract}

Keywords: Governance - Development - Sub-Saharan Africa - Reforms

DOI: $10.7176 / \mathrm{EJBM} / 12-24-05$

Publication date:August $31^{\text {st }} 2020$

\section{Introduction}

Although it is difficult to specify, the concept of governance is used according to two approaches. The first one which is considered as technical and static refers primarily to the administration of State structures and institutions (World Bank, 1989, 1994,2000). The second approach involves actors other than the State. Governance is seen as the conduct of the State and society towards the achievement of societal objectives (Adejumobi 2002; Pierre and Guy, 2000; Hyden, 1999). An attempt to synthesize these two approaches can be found in Kaufmann et al. (2000), Kaufmann (2003) where governance refers to the traditions and institutions through which authority is exercised in a country. This would include: the process by which rulers are chosen, made accountable, controlled and replaced; the ability of governments to manage resources effectively and to formulate and enforce sound policies and regulations; respect for the institutions governing the economic and social interactions between citizens and the State.

There are three main actors in the governance arena: the State, the civil society, and the private sector. The notion of governance is underpinned by a philosophical conception of a social pact between the State and society through which they interactively define national objectives and negotiate the process to achieve them by working collectively, although there may be some tensions and contradictions in the achievement of these objectives (Adejumobi, 2006). The problem, according to Adejumobi (2006) is that of how the national capacity is improved in a free and democratic environment in the best interest of society.

All over the world, countries are working to develop their economies and thereby improve the living standards of their populations. This task is particularly hard in Sub-Saharan Africa (SSA) which has experienced economic decline, growing unemployment, deterioration of basic infrastructure, worsening social inequalities and growing poverty in recent decades. Indeed, $44 \%$ of the population of SSA, i.e. approximately 300 million people, lived on less than one US dollar per day in 2002 (UNSG, 2006 Report); the national income per capita is 746 USD in SSA as compared to 37600 USD in the United Kingdom for example (WORLD DEVELOPMENT INDICATORS (WDI), 2007); life expectancy at birth is 47 years in SSA compared to 79 years in the United Kingdom (WDI, 2007); one fifth of children (20\%) die before the age of five compared to $0.6 \%$ in the UK (World Bank, 2005); $56 \%$ of the population has access to drinking water compared to $100 \%$ in the UK (WDI, 2007).

This situation is mainly due to what is often called bad or rather failing governance: no real rule of law, inadequate protection of property rights, rampant corruption and biased decision-making serving vested interests.

Starting from the commonly accepted assumption that there is a strong correlation between good governance and development objectives (Kaufmann et al 2000, Bourguignon and Sundberg 2007), the purpose of the paper is on the one hand, to explain the failure of governance in SSA, and on the other hand, to explore ways to improve this governance. The rest of the paper is organized according to the following sequence. First, we shall try to identify and examine the determinants of governance failure in SSA (II). Next, we shall discuss the governance reforms necessary to achieve the development objectives in SSA (III) and then we shall point out some limitations of these reforms as well as the factors blocking them (IV). Finally, we shall conclude (V).

\section{2- Determinants of governance failure in Sub-Saharan Africa}

Good governance consists in allocating and managing resources to respond to collective problems; it is characterized by the principles of participation, transparency, accountability, rule of law, efficiency, equity and strategic vision.

In the field, these principles can be experienced through tangible facts such as free and fair elections at regular intervals, a MPs who actually propose, enact laws and exercise control; and an independent judiciary that interprets laws. These principles are also reflected in the respect of human rights, the rule of law as well as the guarantee of 
transparent and accountable institutions. "Good" or "democratic" governance also exists where government authorities rely on the will of the people and are accountable to them. It exists where transparent and democratic institutions allow full participation in political affairs and where the protection of human rights guarantees free expression, association and contestation. Finally, it exists where the government and its institutions defend the poor and the weakest and promote the human development of all citizens. The present and past realities of SSA show that apart from a few rare exceptions (for example Botswana, Mauritius, Namibia, South Africa), these principles are far from being respected. Indeed, in this part of the world described by the World Bank $(2000,2003)$ as the poorest among the poor, we can note the following here and there: non-respect for property rights and basic democratic rules, systemic corruption, arbitrary practices, the wasting and plundering of scarce national financial resources for private interests ...

Three essential factors seem to explain the failure of governance in SSA: dysfunctional institutions, corruption, and the absence of a real democracy.

\subsection{Dysfunctional institutions}

The term institution is defined in different ways. North (1990) makes it a very broad concept designating the formal and informal rules that govern human interactions. Narrow definitions focus on specific organizations, procedures or regulations. At an intermediate level, institutions are defined with reference to the protection of property rights, the fair application of laws and regulations, and corruption. This meaning is narrower than that of NORTH (1990) which includes as mentioned above all the standards governing human interactions. In general, relatively recent research on the determinants of development uses this intermediate definition (Acemoglu (2003); Acemoglu et al (2001), Rodrik and Subramanian (2003), Rodrik, Subramanian et al (2002), Easterly. And Evine (2002), Edison (2003).)

Good institutions have three characteristics (Acemoglu 2003): by guaranteeing the respect of property rights to a large part of the population, they encourage in a wide range of individuals to invest and participate in economic life; by limiting the action of elites, politicians and other powerful groups, they prevent them from appropriating the income or investments of others or from distorting the rules of the game; and by promoting equal opportunities for large sections of society, they encourage investment, especially in human capital, and participation in economic production. Past and present experience shows in many countries, especially in SSA that these conditions are far from being respected, in particular a patrimonial and neo-patrimonial management of the State (the very embodiment of institutions), and a "weak" State prevails there.

\subsubsection{Patrimonial State}

Traditional power in Africa is fundamentally patriarchal in nature; it is based on kinship and is exercised by the elder over his immediate group, the lineage. The patrimonial State corresponds to an extension of this power beyond the family sphere (Weber, 1971). Political patrimonial power is different from other forms of traditional power. It is a power organized around a chief, who exercises his power through the family channel, but also through that of the loyal ones, the servants and the customers who constitute to a certain extent his "administrative general staff". This system is based on the accepted obligation and loyalty of members to chiefs, and not on the quality of the public service they render. The leader's duty is to generously reward those who follow and serve him and to severely punish those who do not show themselves to be sufficiently "cooperative". This "personal government" is characterized by a set of relationships that leaders maintain not with their citizens, but with parents, clients, supporters and rivals and who together form the patrimonial system (Jackson and Rosberg 1982). The State is therefore managed as a "father" does: there is thus a confusion between personal affairs on the one hand and political, administrative and judicial affairs on the other hand. There is no separation between the private and the public domain.

With colonization, and then independence, we kind of went from patrimonial management to neo-patrimonial management of the State affairs.

\subsubsection{Neo-patrimonial State}

In this type of state there is a particular connection between modern bureaucratic norms and patrimonial norms with as a result the existence of specific institutions such as "single political parties", centralized administrations, and the masses often consolidated by an ethnic base (Jacquemot and Raffinot 1993). Ethnicity is pervasive throughout Africa in the political system. Thus, Van Den Berghe (1971) notes that: "In the struggle for posts in the administration, the army, schools and universities, State institutions, private bureaucracies, the surest weapon is ethnic claim, the assurance of political support on an ethnic basis". National allegiance is replaced by regional, tribal, clan or family ties. This situation creates in some countries (Cameroon, Niger, Togo, Nigeria, Rwanda...) an opposition between ethnic groups oriented towards trade and industry, kept away from power and placed under surveillance, and those who hold and occupy all the administration and the army; plainly, those who exercise political power.

This situation largely accounts for the development of emergency economic legislation. The State is no longer seen as the common good of all citizens, but as a "sesame", a "cash cow" that different groups can use for the 
social advancement and enrichment of some people. The political struggle is nothing but the struggle for "food", like Bayart (1989) so well described it. The State appears in fact as the main provider of wealth and the logic is circular (Medard, 1991): "To seek power is also to seek wealth, and to seek wealth is to seek power, since one leads to the other and vice-versa".

\subsection{3 "Weak» State}

The notion of "weak" state, borrowed from Myrdal (1969) characterizes a situation of "functional anarchy" (Jacquemot and Raffinot, 1993): lack of respect for the directives issued by the authority (this is often the case in Niger, Cameroon, Nigeria, DRC, Laurent Gbagbo's Côte d'Ivoire, Taylor's Liberia), collusions between this Authority and pressure groups whose acts should be controlled by the Authority, and the general tendency to evade all forms of administrative control. Corruption is central to this system.

\subsection{Corruption}

Although it is quite difficult to define corruption precisely, just like governance itself, there is a consensus that it refers to acts where the power of a public office is used for personal gain by contravening the rules of the game (JAIN 2001). Certain illegal acts such as fraud, drug trafficking, money laundering, black markets do not in themselves constitute corruption because they do not resort to the use of public power to satisfy a personal economic interest.

Defined in this way we can identify in SSA three types of corruptions: the noble, the bureaucratic and the legislative ones.

Noble corruption ("grand corruption") refers to the acts in which the political elite exploits its positions of power to shape economic policies. Public spending is directed towards the sectors where the gains from corruption are highest, little or no attention is paid to the real needs of the community (Porta and Vannucci, 1997). Although bribes are paid here and there, this type of corruption is difficult to identify when the debate on public policy is in the name of the public interest. "Grand" corruption can have worse consequences on society. The extreme situation of this form of corruption arises when a dictator is at the head of a country and makes no distinction between his personal wealth and that of the country or makes political decisions only to serve his own interests. All things considered, we can say that the regimes of Bokassa (CAR), Sani Abacha (Nigeria), Haile Selassie (Ethiopia), IDI Amin Dada (Uganda), Mobutu (former Zaire) probably corresponded to this extreme situation of noble corruption.

Bureaucratic corruption or "petty corruption" refers to acts of corruption between appointed bureaucrats and their hierarchy (the political elite) or with the public. In its most common form, public users have to bribe bureaucrats either to obtain a service or to speed up administrative procedures (Rose-Ackerman, 1998). Thus, the police, justice, health, education, customs, taxes are sectors often pointed out by the NGO TRANSPARENCY in a certain number of SSA countries (Nigeria, Chad, CAR, Angola...).

Legislative corruption refers to the way and extent to which the voting behaviour of legislators can be influenced. They may receive bribes from the lobbies of business people (usually Western expatriates) or other pressure groups to enact laws favourable to their activities and to block laws harmful to these same activities. This is particularly observed in mining and / or oil-producing countries (DRC, Congo, Sudan, Angola, Chad, Sudan, Cameroon, Nigeria, Niger, Equatorial Guinea).

Whether noble, bureaucratic or legislative, corruption requires the co-existence of three elements (Bliss and Di Tella, 1997; Rose-Ackerman, 1998; Jain 2001): a discretionary power, an economic rent associated with this power, a lax judicial system

2.2.1 Agents' discretionary powers

Above anything else, corruption requires that an individual should have discretion (the authority to set and administer rules) over the allocation of resources. The discretionary powers of the three types of agents - the political elite, administrators, and legislators - differ in terms of the sources of these powers and in terms of their ability to control their "subjects". The elite is chosen by the people to make a defined economic and social policy. This elite acquires extensive powers by the implementation of this policy and it is very difficult to know whether it is made of good politics or not. Besides simple situations leading to nepotism, fraud, tribalism or regionalism it is also difficult to observe corruption on its part. The administrators are appointed by the political elites and delegate their power to them to administer the policies which they have previously defined. The precision of the rules and the cost of monitoring these administrators will determine their leeway in terms of corruption. Just as they choose the political elite, the people also choose lawmakers and observe their voting behaviour. Their discretion lies in the fact that they are drafting legislation that will apply to the other two agents (the political elite and the administrators). The degree of corruption of legislators is solely controlled by the people who have the capacity not to re-elect corrupt legislators.

The three agents thus have incentives to satisfy their own interests at the expense of their principals (behaviour which is fairly illustrative of the principal agent model). The greater the discretion, the stronger the incentives for agents to succumb to the temptation of corruption ceteris paribus (Bliss and Di Tella, 1997). Note, however, that not all uses of power by politicians, legislators, or bureaucrats constitute corruption (Grossman and Helpman, 
1994). The term "discretion", like corruption itself, is difficult to measure (Johnson, Kaufman, Shleifer 1997). In general, discretionary powers are associated with regulations (Rose-Ackerman 1978).

\subsubsection{Economic rent}

The economic rents associated with discretionary powers constitute the second determinants of corruption. The higher the annuities, the greater the incentives for annuitants to try to evade regulations and the higher the bribes they can offer to agents with discretionary power (Braguinsky, 1996). By definition, this could exclude discretionary powers that do not affect the income of identifiable groups. For example, the power of bureaucrats to change regulations that apply to certain aspects of civic behaviour should not lead to corruption. Lack of democracy and poor bureaucracy enable rent seeking to continue (Khan, 2003). Why? First, the absence of democracy increases the likelihood for a small group to continue seeking socially damaging rent (OLSON (2000), (1997), North (1990)). Second, low wages for the bureaucracy, a back-up political bureaucracy, and a poor judiciary can each reduce the anticipated cost of accepting the bribe by the corrupt agents, making rent-seeking more likely (World Bank (1997)

Empirical tests relating to the magnitude of rent excesses are difficult to perform in SSA because it is difficult to estimate the size of such rents. Some authors have nevertheless estimated proxy values of rents in the case of United States (Goel and Nelson, 1998; Jain and Tirtroglu, 2000).

\subsubsection{Lax judiciary}

The third determinant of corruption concerns the functioning of the justice system. Corruption occurs when the justice system offers a sufficiently low probability of detection and / or penalty for the offender, or worse, when the judiciary is itself corrupt.

\subsection{Lack of real democracy}

Modern democracy (understood as the establishment of a State endowed with institutional mechanisms making it possible to avoid the arbitrariness of power and mediating confrontations) according to Jacquemot and Raffinot (1993) is an attempt to overcome neo-patrimonialism as it can only be based on an ever-greater degree of institutionalization of power.

Since the 1990s, social movements have been active in the field of democracy all over the African continent, particularly in SSA. These movements stand out compared to previous movements in reference to the ideology of human rights and by a challenge to the method of sharing both national wealth and international aid. The expression of the protest is first of all urban and, when it is voiced by civil servants, private sector employees and students, its main target is the structural adjustment measures imposed by the IMF and the World Bank which "undermine" their economic and social basis. The protest also quite often concerns the organization of the electoral process and the proclamation of presidential, legislative and municipal elections results (Wade's Senegal, Conté's Guinea Conakry, Obasanjo's Nigeria, Deby's Chad, Eyadema's Togo, Guei's Côte d'Ivoire, Kabila's DRC...). These movements testify to a new maturity of the urban classes which benefit from a higher education and a wider access to information than forty years ago. Moreover, they are based on relatively solid intermediate social groups, and therefore on what deserves to be called "public opinion".

Nothing however guarantees a priori the totally progressive character of these movements, sometimes quickly labelled as democratic. When the most demanding categories are made up of civil servants and students, the complaints are about maintaining the privileges of the welfare State, namely scholarships, the guarantee of outlets, the maintenance of jobs... - so many ingredients typical of an inefficient and expensive civil service - and do not concern the improvement of the living standards of the peasant or the urban underclass. Despite his active participation in demonstrations, the urban underclass remains incapable of formulating a credible demand (Jacquemot and Raffinot 1993).

Democracy intends to redistribute differently, but it cannot develop without resources to distribute. The democratic claim in SSA is based on an ambiguity: it protests against the shortage of political and financial resources, but it may not be able to put an end to it in the short term. The difficulty it encounters is that the stake of the competition is not only political, but economic and political, since access to State functions always directly conditions access to wealth. Under such conditions, democratization will only be able to take root and avoid a return to dictatorships if there is effective social control of the circulation of wealth, if it is a means of limiting prebends by forcing the holders of power "to eat less quickly and less alone".

\section{Governance reforms in ASS}

The classic perception of the State as a "service provider" shows that the role of the State is to ensure law and order, stable property rights, basic public goods, and redistribution to favour well-being. Faced with the inability to provide these elements, State failures imply poorer performance in terms of growth and poverty. This type of State failure has to be associated with a constellation of interrelated governance failures, including corruption and rent-seeking, market distortions and the absence of democracy. From this point of view, governance reforms in SSA can be both political and institutional. 


\subsection{Political Reforms}

Political reforms are understood as a movement towards true democracy and sometimes decentralization, together with encouraging the participation of civil society with a view to limiting the freedom to create arbitrary rents. Democratic governance seems to be the best context for ensuring citizens' participation in decision-making because this participation is necessary in the choice of political leaders and increasing their accountability. This provides local governance and civil society with mechanisms through which citizens can voice their concerns, make decisions at the local level, and inform elected representatives on urgent matters. By providing local government with structures that allow the distribution of resources in a fair, transparent and accountable manner, democratic governance increases citizens' access to services. When decentralization is democratic, it creates a central authority. This makes governance more efficient and more responsive to local needs. The design and implementation of decentralized programmes improve access to basic services such as health care, education and low-cost housing.

\subsection{Institutional reforms}

Institutional reforms include moves to reshape the State to the right size by focusing on the services delivered, reducing the institutional capacity of the State to generate rents, increasing administration salaries by improving recruitment and by increasing the independence of the judiciary.

Fighting against corruption is consistent with all of these reforms and it ensures that incentives to create rents are reduced. The argument is that correcting the failure of the State requires evolving at all of these levels simultaneously. These are the conditions necessary to specifically improve the State's ability to provide public goods and stabilize property rights (World Bank (1997), Asian Development Bank (2000)). Corruption in SSA, as anywhere else in developing countries often results from the diversion of resources from the needy and discourages national and international investments (UNDP (2000)). This has a negative impact on economic growth, income levels and employment. Democratic governance must provide an institutional framework for press freedom, an active role for civil society and a system of checks and balances between executive, legislative and judicial powers - all of which are crucial in the fight against corruption, and in strengthening transparency and accountability in governance.

\section{Limits and obstacles to governance reforms in ASS}

The limits of the reforms can arise from the facts observed and interpreted. The obstacles to the effectiveness of these reforms are socio-cultural, political, legal, institutional and geopolitical factors.

\subsection{Observation and interpretation of facts}

A triple argumentation can be carried out.

First, econometric studies conducted in SSA as elsewhere have found that governance variables such as corruption, the stability of property rights or even democracy are correlated with development objectives such as per capita income, per capita income growth, the investment rate and direct measures of poverty such as the child mortality rate (see for example, Hall and Jones (1999), Kaufman, Kraay and Zoido-Lobaton (1999), Johson, Kaufman and Zoido-Lobaton (1998), Clague, Keefer et al. (1997), World Bank (1997), Knack and Keefer (1997, 1995), Barro (1996), Mauro (1995)). However, Khan (2003) wonders whether the rush to establish that all good things go together has not influenced the measurement and interpretation of facts? Most of the studies conducted on these studies present their results with caution, which ultimately suggests that extra care should be taken when interpreting the results. It should be noted that not all econometric work adheres to the thesis of the link between governance and development. In particular, Treisman (2000) shows that the effects of democracy and decentralization on corruption are very weak. Burkhart and Beck (1994) show that it is the increase in per capita income that precedes the emergence of democracy and not the other way around.

Next, Khan (2003) argues that indicators for measuring the quality of governance are subjective by their nature in such a way that corruption, democracy, stability of property rights and even the degree of 'distortion' induced by politics are measures of indicators based on perception, judgment, of "competent" observers. By constructing a composite governance indicator, previous expectations can introduce a bias in the choice of evidence and weights. In addition, the general lack of time series data makes it difficult to carry out causality tests between governance variables and development objectives.

Finally, while admitting that corruption has a cost, Khan (2002 b) really raises the question of the level from which sustained reductions in corruption or from which improvements in democracy can be attained before economic prosperity in the broad sense is achieved, and more importantly, whether these governance reforms are likely to accelerate economic growth enough to have an impact on poverty.

\subsection{Society and Culture}

Some anthropological and sociological theses commonly mentioned maintain (though without scientific 
foundations) that the behaviours and attitudes of individuals in sub-Saharan African societies are characterized by the following traits: magico-religious or prelogical or even pre-Newtonian mentalities, old value systems, fatalism, tribalism or regionalism, blind obedience to the leader, conservatism, immobility and pusillanimity. These characteristics are opposed, according to the proponents of these theses, to the principles of democratic governance and therefore to the economic development of Africa. The values and behaviour of individuals would be incompatible with the introduction of democratic principles, of rational and transparent management of resources. Their behaviour would therefore be anti-democratic and anti-economic.

\subsection{Law and Politics}

The absence of a rational legal order and security in trade, and the non-respect of contracts are likely to set back governance. For example, robbery in the south of Madagascar has led to a fall in agricultural production. The guerrillas and rebellions in Ethiopia, Angola, Mozambique, Sierra Leone, Sudan, Somalia and Côte d'Ivoire have pushed these countries decades back.

\subsection{Institutions and Geopolitics}

A country torn into rival ethnicities (Rwanda, Sudan, Nigeria, DRC, Côte d'Ivoire), an insufficiently strong and respected State, lack of efficient, honest and competent public service will be bottlenecks in the democratic governance and development policies. Geopolitical factors can also influence the management of public affairs in SSA. Therefore, is it possible to carry out reforms of this management without addressing the geopolitical aims of South Africa and Angola, not to mention the ambitions of the Nigerian pole and the fears they provoke on the neighbouring countries, or on the future of the countries of East Africa, not to mention the conflict between the USA and Sudan which suddenly increases the geopolitical interest of Angola?

\section{Conclusion}

The purpose of this paper was to try to explain on the one hand the failings of governance in SSA and, on the other hand, to identify the reforms likely to remedy them. It appears that these failures are mainly due to dysfunctional institutions, corruption among governance actors, and the absence of a true democracy. The dysfunction of the institutions is the consequence of a patrimonial and neo-patrimonial management of the State. Corruption appears as the manifestation of the discretionary power of certain agents and takes three main forms: noble, bureaucratic and legislative. The electoral process in general still remains marred by many irregularities at least in its practical functioning, reflecting undemocratic behaviour.

Possible governance reforms can be both political and institutional. Political reforms should promote and strengthen democratic practices. The institutions must guarantee the rule of law and respect for the property rights of agents, limit the political and economic power of the elites, promote equal opportunities for individuals, encourage access to education and the participation of a large segment of the population in economic production. The limits to these reforms lie in the observed and interpreted facts (causal relationships not established between governance variables and development objectives). The sources of blockages to reforms would arise from sociocultural factors (conservatism, magical and religious mentalities, cult of the leader, pusillanimity), political and legal (ethnic conflicts, weak state, non-respect of contracts, insecurity of trade), institutional (refusal of formal or non-formal) and geopolitical (hegemonic ambitions of certain States: Nigeria, South Africa).

\section{Rererences}

Acemoglu D. (2003), « Causes Profondes de la Pauvreté. Une perspective historique pour évaluer le rôle des institutions dans le développement économique », Finances et Développement, Juin 2003, 40, n 2, pp 27-30

Adejumobi S. (2006), "Governance and poverty reduction in Africa: A Critique of the Poverty Reduction Strategy Paper (PRSPs)", Paper Presented to the Inter-Regional Conference on Social Policy and Welfare Regimes in Comparative Perspectives, University of Texas in Austin, U.S.A, 30 p.

Adejumobi S. (2002), "Democracy and Good Governance in Africa: Theoretical and Methodological Issues", in Bujra A. and Adejumobi S. (eds.), Breaking Barriers, Creating New Hopes: Democracy, Civil Society and Good Governance in Africa (Tenton, New Jersey: Africa World Press).

Asian Development Bank (2000), "Promoting Good Governance: ADB's Medium-Term Agenda and Action Plan", Manila.

Bayart J-F. (1989), « L’Etat en Afrique, la politique du ventre », Paris, Ed. Fayart

Barro R. (1996), « Democracy and Growth », Journal of Economic Growth, 1, n 1, pp.1-27

Bliss C. and Di Tella R. (1997), "Does Competition Kill Corruption?" Journal of Political Economy, 105, n 5 pp 1001-2

Braguinsky, S.(1996), "Corruption and Schumpeterian Growth in different economic environments", Contemporary Economic Policy, 14, pp. 14-25.

Bourguignon F., Sundberg M.(2007), « L’Aide peut donner des Résultats, » Finances et Développement, Mars 
2007, 44, $\mathrm{n}^{\circ} 1$, pp. 56-57.

Burkhart R. Lewis-Beck M. (2013), "Comparative Democracy: The Economic Development Thesis", American Political Science Review, 88, pp. 903-910.

Clague C, Keefer P . et al.(1997), "Democracy Autocracy and the Institutions Supportive of Economic Growth", in Clague, Christopher éd., Institutions and Economic Development : Growth and Governance in LessDeveloped and Post-Socialist Countries, Baltimore, The Johns Hopkins University Press.

Easterly W., Ross L. (2002), "Tropics, Germs and Crops: How Endowments Influence Economic Development" NBER Working Paper 9106 (Cambridge, Massachusetts: National Bureau of Economic Research).

Edison H.(2003), "Qualité des Institutions et Résultats Economiques .Un lien étroit ? » Finances et Développement, Juin 2003, 40, ${ }^{\circ} 2$, pp. 35-37.

Goel R. K. and Nelson M .A (1998), "Corruption and Government size: a disaggregated analysis", Public Choice, 97, pp.107-20.

Grossman G. M. and Helpman E. (1994), Protection for sale. American Economic Review, 84, n4 4 , pp.833-50.

Hall R., Jones Ch. (1999), Why Do Some Countries Produce So Much More Output Per Worker Than Others? Quarterly Journal of Economics, 114, pp.83-116

Hyden G. (1999), "African Governance Barometer: Measurement and Monitoring Issues" Paper Presented to the United Nations Economic Commission for Africa (UNECA) Worsksop on "Indicators for Monitoring the Progress Towards Good Governance in Africa, Addis Abeba, Ethiopia, September 1999.

Jain A. K. (2001 ), "Corruption: A review" Journal of Economic Surveys, 15, n¹ pp.72-111

Jain A. K., Tirtiroglu D. (2000), "Globalization and Rent Seeking in Financial Services Industry. Unpublished paper"; Montréal : Concordia University.

Jackson R., Rosberg C. (1982), "Personal Rule in Black Africa, Autocrat, Prophet, Tyran", Berkeley, Ed. University of California Press.

Jacquemot P., Raffinot M.(1993), "La Nouvelle Politique Economique en Afrique”, Ed;. Edicef/Aupelf, 351 p .

Johnson S., Kaufman, D. et al. (1998), "Regulatory Discretion and the Unofficial Economy", American Economic Review, 88, pp. 387-392.

2, pp.159-239.

Kaufmann D. (2003), "Rethinking Governance: Empirical Lessons Challenge Orthodoxy", Mimeograph.

Kaufmann D. , Kraay A. et al. (2000), "Gestion des Affaires Publiques. De l'évaluation à l'action", Finances et Développement, juin 2000, 37, $\mathrm{n}^{\circ} 2 \mathrm{pp} .10-12$.

Khan M.H. (2003), State Failure in Weak States : A Critique of New Institutionalist Explanations, in John Harris, Janet Hunter and Colin M. Lewis, eds, The New Institutional Economics and Third World Development, London, Routledge.

(2002), Corruption and Governance in Early Capitalism :World Bank Strategies and their Limitations , in Pincus , J. \& J. Winters, (eds) Reinventing the Third World Bank, Ithaca, Cornell University Press.

Knack S., Keffer Ph.(1997), Why Don’t Poor Countries Catch Up? A Crosss-Country Tests Using Alternative Institutionnal Measures, Economic Enquiry, 35, pp. 590-602.

Knack S., Keffer Ph. (1995), Institutions and Economic Performance : Cross-Country Tests Using Alternative Institutionnal Measures , Economics and Politics, 7, n³ , pp. 207-227.

Mauro P. (1995), "Corruption and Growth" Quartely Journal of Economics, 110, n³, pp 681-712.

Medard J.-F. (1991), Etats d'Afrique noire, Formations, mécanismes et crise, Paris, Ed. Karthala 1991.

Myrdal G. (1969), « L’Etat « mou » dans les pays sous-développés, Tiers Monde, Tome X, n 37.

North D. C.(1990), Institution, Institutional Change and Economic Performance, Cambrigde, Cambridge University Press.

Olson M. (2000), Dictatorship, Democracy and development, in Mancur Olson Satu Kähkönen eds, A Not-soDismal Science: A Broader View of Economies and Societies, Oxford: Oxford University Press.

Olson M. (1997), The New Institutional Economics: The Collective Choice Approach to Economic Development, Institutions and Economic Development in Christopher Clague ed, Baltimore, John Hopkins University Press.

Pierre J. and Guy B. (2000), Governance, Politics and the State. London, Macmillan Press.

Porta D. D., Vannucci, A. (1997), The Perverse Effects of Political Corruption. Political Studies, 45 (Special Issue), pp.516-38.

Rodrik D. Subramania A.( 2003), La Primauté des Institutions, Finances et Développement, 40, n 2, pp. 31-34.

Rodrik D. Subramania A. et al. (2002), Institutions Rule: The Primacy of Institutions over Geography and Integration in Economic Development, NBER WORKING Paper 9305 (Cambridge, Massachusetts : National Bureau of Economic Research).

Rose-Ackerman S. (1997), Corruption and Development. Annual World Bank Conference on Development 
Economics, pp. 35-57.

-(1978), Corruption: A Study In Political Economy. Academy Press.

Treisman D.( 2000), "The Causes of Corruption: a cross-national study". Journal of Public economics, 76, (2000 June), pp. 399-457.

World Bank (2003), Progress on Poverty Reduction. 1998-2000. (Washington, DC: World Bank). -(2000), Can Africa Claim the $21^{\text {st }}$ Century? (New York: Oxford Press).

-(1994), Adjustment in Africa: Reforms Results and the Road Ahead (New York: Oxford University Press)..

, Sub-Saharan Africa: From Crisis to Sustainable Development (New York: Oxford University Press) 